\title{
Integrating land use planning and water resource management: threshold scenarios - a tool to reach sustainability
}

\author{
M. I. Rodríguez ${ }^{1}$, A. L. Grindlay ${ }^{1}$, M. M. Cuevas ${ }^{1} \&$ M. Zamorano ${ }^{2}$ \\ ${ }^{I}$ Department of Urban and Regional Planning, \\ University of Granada, Spain \\ ${ }^{2}$ Department of Civil Engineering, University of Granada, Spain
}

\begin{abstract}
The relationship between water and territory has been determined throughout history by the successive construction of water infrastructures. From the first agricultural canals to the present day, water networks have transformed the territory, favouring the creation and development of human settlements, but also resulting in severe impacts. The complexity achieved by these networks and its environmental effects require the establishment of coordinated strategies between Land Use Planning and Water Resource Management, to generate sustainable land use scenarios. In this sense, threshold scenarios are proposed as a convenient tool to limit the uncertainty and determine the impacts of water infrastructures on the territory, helping with decision making and anticipating possible deviations from the plans' forecasts. In this paper a study on the coast of Granada (Spain) is presented. It shows the importance of including threshold scenarios in an integrated water resource management, as a tool that can be used in the strategic environmental assessment to evaluate territorial integration in water management. Keywords: land use planning, integrated water resource management, threshold scenarios, sustainability.
\end{abstract}

\section{Introduction and objectives}

Throughout history, water management models have been based on principles that have evolved with the needs and challenges of each location and time. Traditionally water was considered as a factor of production and an unlimited resource, which allowed the growing demands on that water be satisfied through 
the construction of hydraulic infrastructure, creating expectations of growth which were translated into greater demands ad infinitum [1]. This unsustainable process has caused the deterioration and depletion of water resources, as well as a growth rate greater than many territories could support [2]. For this reason since the 1980s a more rational management of water has been demanded, which considers water as an eco-social asset. This change of perspective has been represented fully in the bibliography. There are many references that allude to this under different appellatives; 'hydraulic culture' against 'hydrologic culture' [3], 'supply driven ethos' against 'demand management ethos' [4], 'period of water development' against 'period of water management' [5], 'traditional planning' against 'integrated resource planning' [6], 'supply management era' against 'demand management era' [7], 'a time of resource exploitation' against 'a time of changing focus' [8].

These new principles involve the need to carry out water management from a more integrated and less segmented focus, in which all the disciplines meet and that in one form or another are represented in the problems of water. Thus in the 1990s 'Integrated Water Management' was being explored [9-11] as a methodology to join all these variables in a new form of managing this most valuable resource, which became incorporated into the Water Framework Directive [12], relating to the need to carry out an integration of territorial and hydrological policies.

Currently many references exist that confirm the application of these new principles [13-15], however, the majority of them continue to hold sectorial views, as so many of the authors call attention to the lack of consideration of territory in this new model [16-18]. Neither the water management plans nor the territorial management plans have given sufficient response to territorial needs [19, 20], to a certain extent, due to the absence of specific mechanisms in the Water Framework Directive that affect the instruments of territorial planning [21]. This has meant that sectorial approaches have continued to be perpetuated, resulting from the competitive compartmentalization between management administrations [23]. This deficiency implies a challenge for contemporary society and defines the principle objective of this paper, to contribute to the integration between Land Use Planning and Water Resource Management, beyond the different understandings of the administrations that manage them, and to foster their interdependence wherever possible. In this way, the Directive on Strategic Environmental Assessment [24], a tool for the environmental evaluation of plans and programs, could be utilized as a legal framework for the evaluation of the integration of territory in Water Resource Management.

\section{Hypotheses}

Despite reaching a general consensus on the need to undertake an Integrated Water Management approach which is integrated with Land Use Planning, the basic principles of this integration have not been clearly defined [25]. The first consideration to take into account is that these principles lack universality, indeed that the factors vary according to the characteristics of the region; the natural environment and the intensity of the water problems, the human resources, the 
institutional capacities, the peculiarities of the public and private sector, the cultural aspects [26]. However, there are a series of common elements in most of the territories, that structure the relationship between Land Use Planning and Integrated Water Management [27, 28], and therefore define the hypotheses of this paper. The first of these relates to the investment between infrastructure and growth. It is clear that the creation of infrastructures has a great influence on the territory, as the provision of new services generates an expectation of development which enables potential growth, and then limits it when it has reached levels higher than those available. This is clearly demonstrated both with transport as well as hydraulic infrastructures, as an increase in accessibility and/or availability of water generates a development of activities in the environment of the newly supplied areas $[29,30]$. The second hypothesis is based on the fact that the forecasted growth in water management plans is usually lower than the actual growth. This normally occurs because irrigated areas end up being completely utilized, despite this growth not being planned [18, 31, 32]. The third and final hypothesis explores the environmental impacts that this excess of growth produces on the territory, causing sometimes irreparable damage (over-exploitation of aquifers, erosion, contamination of water, etc.) [33-36]. One of the principle environmental impacts is the water deficit, as the water requirement exceeds the projections, and therefore, the existing water availability. This fact generates a social demand for water that usually culminates in the creation of new hydraulic infrastructures, culminating in "a vicious circle" that continually creates more impacts on the territory $[1,18,21]$ (fig. 1 ).

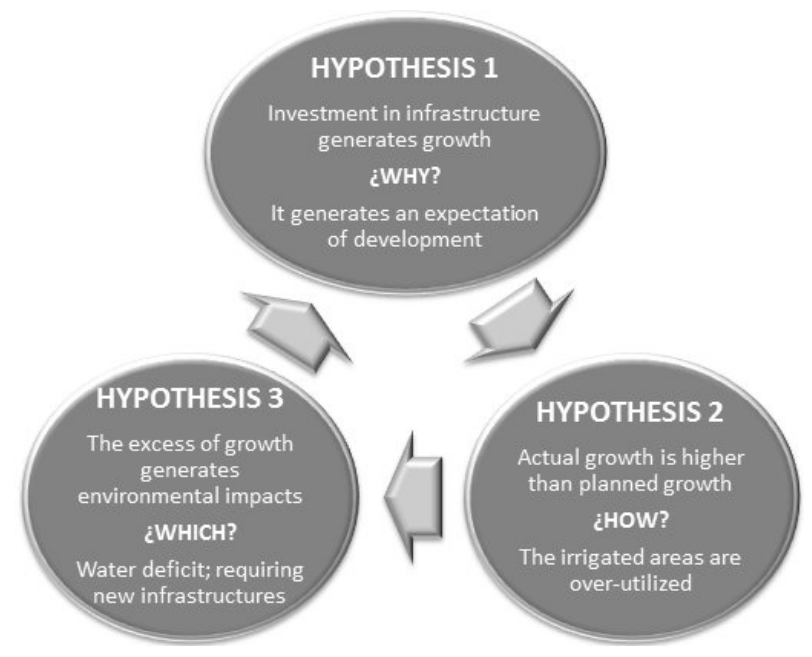

Figure 1: Hypotheses and circle of unsustainability.

These interrelationships define the principle objective of this paper; to determine a tool which allows control of the growth produced and breaks this cycle of unsustainability prevalent, even today, throughout all Mediterranean countries [21]. 


\section{Methodology}

Starting from the defined hypotheses, the methodology used comprises of analysing each one in a pilot region, with the objective of detecting the waterterritorial interactions that prove to be crucial for the definition of a tool to control growth. The zone chosen as a field study was the coast of Granada, in the region of Andalusia, southern Spain (fig. 2). In this zone, the water-territorial relationships have been very strong throughout its history, and the huge growth produced in recent years makes it a location where it is perhaps even more necessary, if that is possible, to develop tools that allow the generation of sustainable scenarios $[18,21,31]$. Thus, the regional administration has developed the 'Territorial Plan for the area of the Costa Tropical of Granada', the principle objective of which has been to establish the framework of reference for the sustainable organization and development of Granada's littoral, with the aim of guaranteeing and making compatible the preservation of environmental and territorial resources, with socio-economic progress and the improvement of the quality of life for its inhabitants [37]. With an area of $23.87 \mathrm{~km}^{2}$; this region has an irregular hydrological cycle, a high environmental quality and diversity, large infrastructural development and elevated current and future water demands (all the hypotheses are fully represented). It is a territory totally involved in the process of transformation after the improvement of the principle infrastructures, both transport and hydraulic, whose potential for future development is based fundamentally in agriculture and tourism [37].

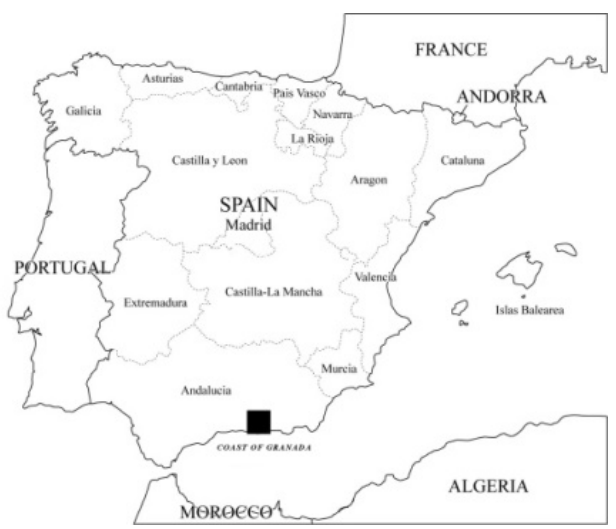

Figure 2: Coast of Granada location.

Despite all of the above, there is a recognition that the Plan has not responded to the new demands and problems of the region, consequently it has established a series of strategies aimed at territorial integration, re-evaluation of economic activities and the prizing of natural, cultural and scenic resources. However, this document lacks concrete proposals that provide limits to the uncontrolled growth produced in the region in the last 50 years which has perpetuated an unsustainable water management model. 


\subsection{Investment in hydraulic infrastructure to generate growth}

The pluviometric variability, typical of the Mediterranean regions, has always necessitated hydrological planning to be based on the management of extreme phenomena (droughts and floods) and, therefore, the construction of many hydraulic infrastructures to store, retain and control the water [38]. Furthermore, the mountainous geography of the area generates fast flowing run-off and does not allow for the 'natural storage of water' which consequently encourages the use of unregulated water resources [39], so that water management becomes a far more complex task. Thus, the inadequate availability of water combined with the limited natural regulation of water, has promoted the creation of multiple hydraulic infrastructures that have allowed the storage, retention and control of the water resources, increasing its availability and allowing the development of the territory [40]. However, counter-intuitively, this phenomenon has not resulted in a reduction of the water scarcity, but rather the complete opposite. In the Andalusian hydrographic basins, a significant increase in the availability of water resources in recent years has paradoxically led to a greater water deficit [18, 21]. Specifically, on the coast of Granada, the estimation made by the Hydrological Plan indicates a deficit of $4 \mathrm{Hm}^{3}$ in 2015 and some $7 \mathrm{Hm}^{3}$ in 2025 [41]. The successive investments in the hydraulic infrastructure have produced an occupation of the adjacent areas in a manner at times uncontrollable [42]. Fig. 3 shows how the construction of irrigation channels to heights of 50,100 and 200 metres, has almost completely determined the growth of agriculture in the zone, over-utilizing the irrigated areas and generating a massively significant environmental impact on the territory [43].

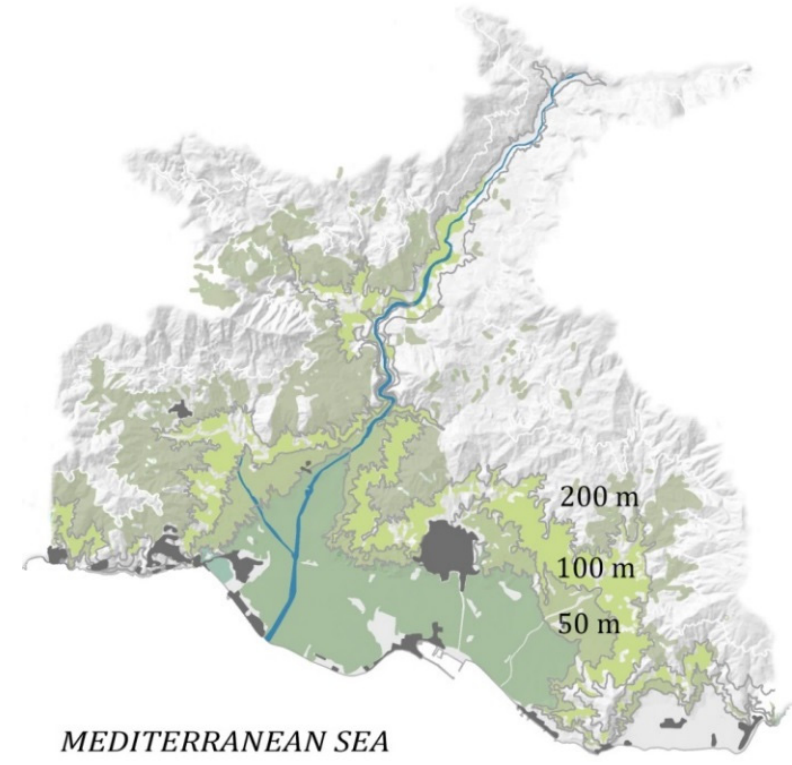

Figure 3: Evolution of the growth of agriculture and its relationship to the hydraulic infrastructure on the coast of Granada. 


\subsection{Growth is greater than anticipated}

As the Plan demonstrates, the growth of the agricultural area on the coast of Granada has been spatially determined by the development of the hydraulic infrastructure, generating an expectation of growth which has meant that $99 \%$ of areas able to be irrigated are currently being irrigated (DHCMA, 2010), and that the water deficit is ever greater. This growth has not been linear, but rather, as Malisz pointed out, “... the process of territorial expansion is of a terraced or stepped character that is not continuous, but rather that occurs in jumps coinciding with the creation of the infrastructures ..." [44]. In the case of the coast of Granada, these jumps have coincided with the creation of a succession of irrigation channels that have functioned as triggers for growth approximately every 10 years (fig. 4).

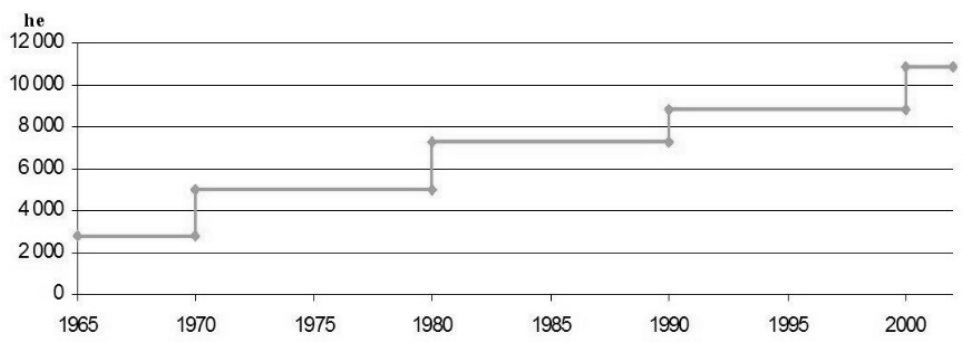

Figure 4: Increase of the irrigated area in relation to the creation of the hydraulic infrastructure on the coast of Granada.

These stepped jumps, generally unplanned, have meant that the growth forecasts in the plans have been completely exceeded in reality. In Andalusia, the forecasts made by the various plans have been considerably less than the actual growth produced (fig. 5), generating a significant water deficit which is causing serious problems in the region (environmental, economic, social) [31].

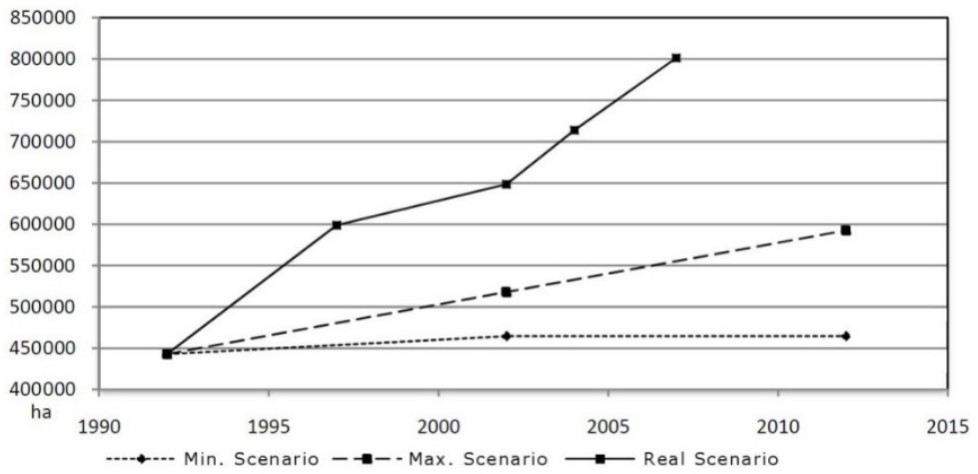

Figure 5: Growth forecasts and real growth of irrigated areas within Andalusia [45]. 


\subsection{Growth without planning generates impacts on the environment}

On the coast of Granada agricultural use is the principal consumer of water in the region. In fact, this demand accounts for almost $90 \%$ of the total demand [40]. Thus an increase in the irrigated area in relation to that forecasted in the plans can imply serious environmental problems relating, amongst others, to the quantity and quality of the water [43].

On the coast of Granada, in 2003 the possibility of building a new channel to the height of 400 metres was established, which would supply new irrigated areas [46]. The current economic crisis has paralyzed this process, at least for the immediate future. As a result of this, a prediction has not been carried out on the territorial consequences that this new infrastructure could create. It is therefore necessary to establish coordination strategies between Land Use Planning and Water Resource Management that use the hydraulic infrastructures as a tool to rebalance the territory, and not, as has happened in this region, as an enablement to its imbalance [21].

Hence, a basic principle of coordination between both plans must be to limit the territorial uncertainty that the creation of an infrastructure would generate, by means of the creation of a 'Threshold Scenario' that quantifies the maximum growth that this infrastructure could cause, as well as the associated demands that would be produced. Utilizing this forecast of maximum growth, an evaluation must be made as to whether the expected growth would imply an acceptable risk for the affected territory or not. If the growth follows historical trends it could follow that the creation of this infrastructure would generate more damage than benefit, which may lead to its construction being rejected. So, using this tool, it would be possible to avoid the recurring phenomenon of recent years, where growth has always exceeded the forecasted scenarios, causing serious, mainly irreversible, environmental impacts.

In the case of the coast of Granada, after developing the Threshold Scenario associated with the creation of the infrastructure proposed in 2003 [21] (fig. 6), it can be seen that the increase of irrigated area that it could produce would be some four times higher than that generated in recent infrastructural jumps (fig. 7), causing a water deficit of almost $50 \mathrm{Hm}^{3}$ [21]. The information generated by this Threshold Scenario would prove indispensable when deciding on the advantageousness or otherwise of this infrastructure, as well as for establishing preventative measures if the construction is finally completed. In this way, the maximum demands would be limited and programmes could be established that augment the available water resources (improve the efficiency of networks, water re-use, desalination) and generate a strategic reserve against a possible increase in consumption. This would avoid the 'improvisations' that are produced when demands exceed forecasts, which generally lead to the use of subterranean resources when surface resources are insufficient. This has generated the over-use of most coastal aquifers throughout the Mediterranean, many of them already irreversibly so [47]. 


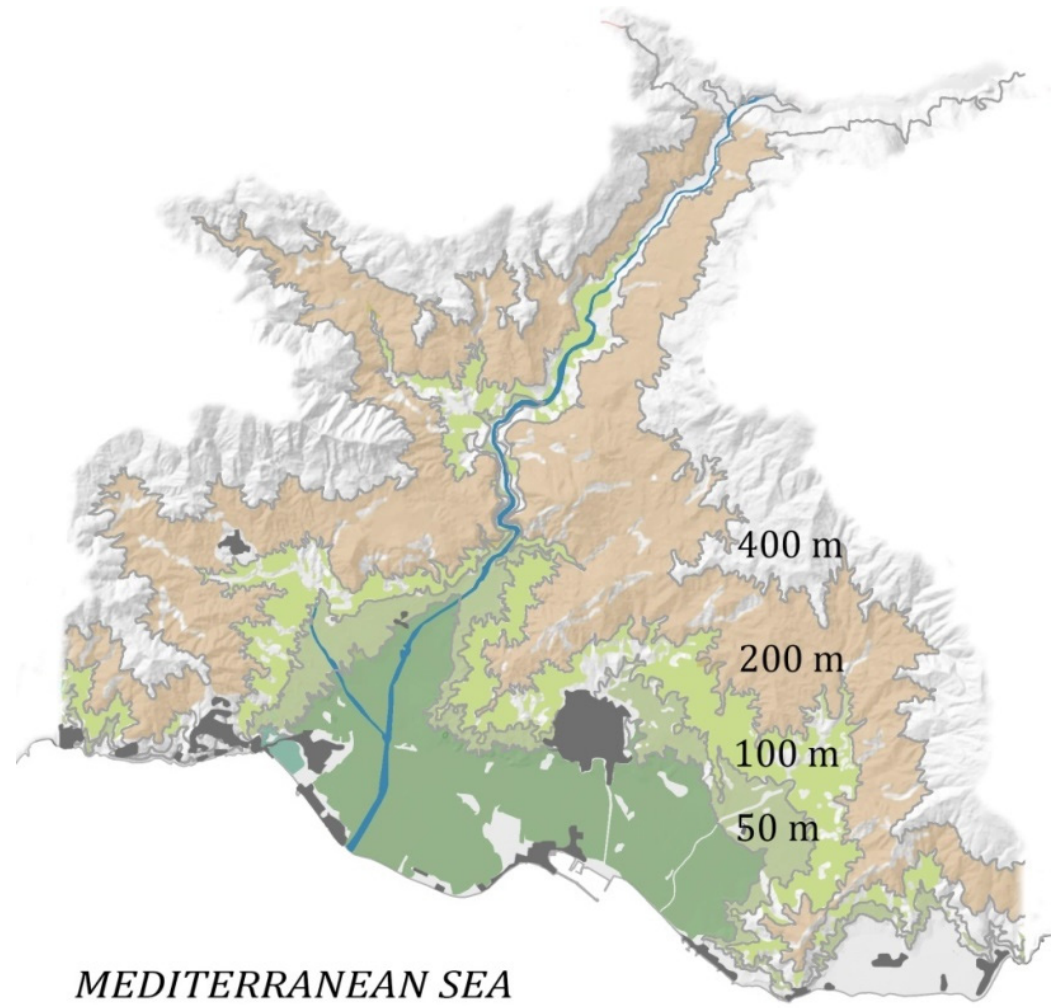

Figure 6: Threshold Scenario associated with the channel from the height of 400 metres on the coast of Granada.

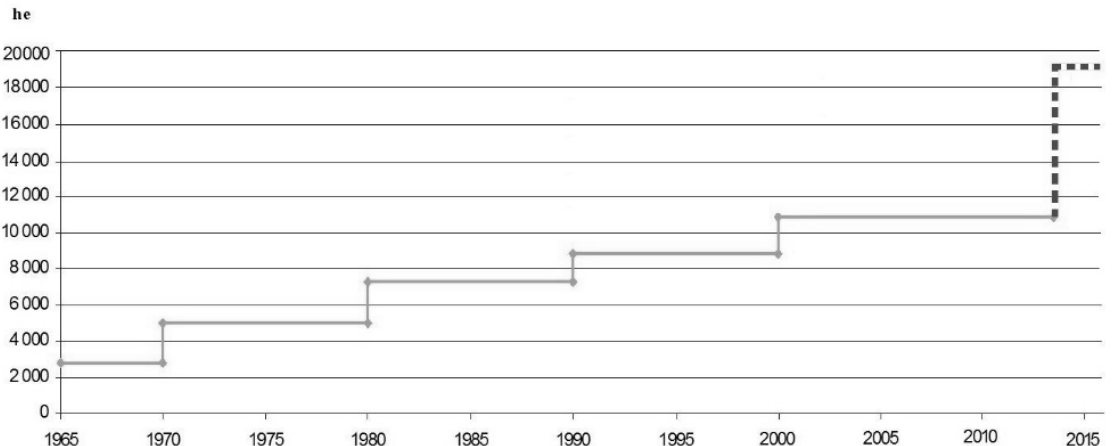

Figure 7: Agricultural growth corresponding to the Threshold Scenario associated with the channel from the height of 400 metres on the coast of Granada. 


\section{Conclusions}

According to the study, the increase in the availability of water through construction of hydraulic infrastructure as a response to the growth of demand, has not affected a decrease of the water deficit, but rather to the contrary, it has caused an unsustainable situation that is having serious environmental consequences. This has happened because the growth forecasts in the plans have been totally exceeded by the actual growth, leading to a 'water shortage' that has established a considerable fragility in the territories and has caused serious conflicts over water usage. Therefore it is necessary to establish strategies of coordination between Land Use Planning and Water Resource Management, which enable sustainable scenarios to be generated, putting an end to this recurrent phenomenon. Thus, the creation of 'Threshold Scenarios' facilitates the quantification of maximum growth that can be generated and the evaluation of the advantageousness of constructing new infrastructures, limiting the uncertainty and risk generated by the expectation of growth in a territory, and establishing preventative methods that avoid future mismanagement of the water resource. In this way, the planning of the hydraulic infrastructures are carried out without forgetting that they are a crucial element in Land Use Planning and that they play an important role in the development of regions, thus helping to improve the future sustainability within territories.

\section{References}

[1] Del Moral, L., Aspectos territoriales de la gestión del agua: de la idea de factor de desarrollo al debate sobre la capacidad de carga. El Plan Hidrológico Nacionaldesde el Sur. Comares, Granada, 2002.

[2] Arrojo, P., I Congreso Ibéricosobre Planificación y Gestión de Aguas. Universidad de Zaragoza, 1998.

[3] Newson, M.D., Land, Water and Development. Sustainable management of river basin systems. London, 1992.

[4] Abrams, L. J., Policy Development in the Water Sector - The South African Experience. Water Policy: Allocation and Management in Practice. Peter Howsam y Richard Carter, (eds.). Londres, E \& FN Spon: pp. 21-30, 1996.

[5] Dzurik, A., Water Resources Planning. Lanham, Maryland, Rowman \& Littlefield, 1996.

[6] Beecher, J. A., Integrating Water Supply and Water Demand Management. Urban Water Demand Management and Planning. Duane D. Baumann, John J. Boland y Michael W. Hanemann, (eds.), McGraw-Hill: pp. 303-327, 1998.

[7] Turton, A., Water Scarcity and Social Adaptive Capacity: Towards an Understanding of the Social Dynamics of Water Demand Management in Developing Countries. Presented to the Water Issues Study Group, School of Oriental and African Studies (SOAS), MEWREW Occasional Paper N ${ }^{\circ}$, 1999. 
[8] Thompson, S. A., Water Use, Management and Planning in the United States. San Diego, Academic Press, 1999.

[9] Mitchell, B., Integrated water management: international experiences and perspectives, 1990.

[10] Wisserhof. J., Enhancing research utilization for integrated water management. Water Science and Technology, 31 (8), pp. 311-319, 1995.

[11] Geldof. G.D., Adaptive water management: Integrated water management on the edge of chaos. Water Science and Technology, 32 (1), pp. 7-13, 1995.

[12] European Parliament and Council, Water Framework Directive. Directive 2000/60/EC, 2000.

[13] Lenton, R., Integrated Water Resources Management. Reference Module in Earth Systems and Environmental Sciences, 1, pp. 9-21, 2011.

[14] Ferguson, B.C., Brown, R. R., Frantzeskakid, N., de Haana, F.J., Deletic, A., The enabling institutional context for integrated water management: Lessons from Melbourne. Water Research, 47 (20), pp. 7300-7314, 2013.

[15] Ludwig, F., van Slobbe, E., Cofino, W., Climate change adaptation and Integrated Water Resource Management in the water sector. Journal of Hydrology, 518 (B), pp. 235-242, 2014.

[16] Solanes M., González-Villarreal F., Los principios de Dublín reflejados en una Evaluación Comparativa de Ordenamientos Institucionales y Legales para una Gestión Integrada del Agua. TAC Background papers Vol. 3. Global Water Partnership, 2001.

[17] Riechmann, J., Biomímesis. Ensayosso breimitación de la naturaleza, ecosocialismo y autocontención. Ed. Los Libros de la Catarata, Madrid, 2006.

[18] Valenzuela, L.M., Matarán, A., Environmental indicators to evaluate spatial and water planning in the coast of Granada (Spain). Land Use Policy, 25, (1), pp. 95-105, 2008.

[19] European Spatial Development Perspective, European Commission, Postdam, May 1999.

[20] España Villanueva M., \& Valenzuela Montes L.M., Implicaciones de la recientenormativa de aguas: Valoración de la respuesta de los planes territoriales Andaluces. Observatorio Medioambiental, 16, pp. 207-227, 2013.

[21] Rodríguez, M.I., La Planificación territorial del agua en la Región del Guadalfeo. Ph.D. Thesis, University of Granada, 2008.

[22] Dooge, J., Hydrologic science and social problems. Arbor CLXIV, 646, pp. 191-202, 1999.

[23] Moss, T, The governance of land use in river basins: prospects for overcoming problems of institutional interplay with the EU Water Framework Directive. Land Use Policy, 21, pp. 85-94, 2004.

[24] European Parliament Council. The Strategic Environmental Assessment Directive 2001/42/ EC. Official Journal L197 of 21 July 2001, p. 30, 2001.

[25] Born, S.M., Kenneth, D., Genkskow, K.D., Toward understanding new watershed initiatives Madison Watershed Workshop. University of Wisconsin-Madison, USA, 2001. 
[26] Mitchell, B., Integrated water resource management, institutional arrangements, and land-use planning. Environment and Planning A, 37, pp. 1335-1352, 2005.

[27] Carter, N., Kreutzwiser, R.D., de Loë, R. C., Closing the circle: linking land use planning and water management at the local level. Land Use Policy, 22(2), pp. 115-127, 2005.

[28] Grindlay, A.L., Zamorano, M., Rodríguez, M.I., Molero, E., Urrea, M.A., Implementation of the European Water Framework Directive: Integration of hydrological and regional planning at the Segura River Basin, southeast Spain Land Use Policy, 28(1), pp. 242-256, 2011.

[29] Bröcker, J., Capello, R., Lundqvist, L., Pütz, T., Rouwendal, J., Schneekloth, N., Spairani, A., Spangenberg, M., Spiekermann, K., Vickerman, R., Wegener, M., Impact territorial des politiques de transport européennes et des politiques de réseauxtranseuropéens. Territoires 2020, 11, pp. 63-74, 2004.

[30] Costejá, M., Font, N., Rigol, A., Subirats, J., The evolution of the national water regime in Spain. EUWARENESS Project, Universitat Autonoma de Barcelona, Spain, 2002.

[31] Frontana, G.J., Agua y territorio. Recursos y conflictos de usos en Andalucía y en la Costa de Granada. Ed. Universidad de Granada, Col. Monográfica Tierrasdel Sur, Motril, Granada, 2002.

[32] Grindlay A.L., Zamorano M., Rodríguez M.I., Molero E., Urrea M.A., Territorial Transformation and Water Utilization: Hydrological Planning Scenarios in the Segura River Basin. WIT Transactions on Ecology and the environment, 120, pp. 975-984, 2009.

[33] Olcina, C.J., Riesgo de inundaciones y ordenación del territorio en la escala local. El papel del planeamientourbano municipal, Boletín de la A.G.E., 37, pp. 49-84, 2004.

[34] Pirrone, N., Trombino, G., Cinnirella, S., Algieri, A., Bendoricchio, G., Palmeri, L. The driver-pressure-state-impact-response (DPSIR) approach for integrated catchment-coastal zone management: preliminary application to the Po catchment-Adriatic Sea coastal zone system. Regional Environmental Change, 5(2-3), pp. 11-137, 2005.

[35] Margat, J., Progress towards water demand management in the mediterranean region. Contemporary trends and water demand change perspectives in the Mediterranean countries. Plan Bleu, Regional Activity Centre, Sophia Antipolis, Greece, 2002.

[36] Velásquez Alonso, E., Modelo Input-Output de agua. Análisis de las relaciones intersenctoriales de agua en Andalucía.(E2003/01), Fundación Centro de Estudios Andaluces, Technical Report, 2003.

[37] Consejeríade Obras Públicas y Vivienda, Plan de Ordenación del Territorio de la Costa Tropical de Granada, Junta de Andalucía, Sevilla, 2012.

[38] Arnell N. W. Climate change and global water resources. Global of environmental change. 1(9), pp. S31-S49, 1999. 
[39] Juanicó M., Salgot M., Water reuse in the northern Mediterranean. Technical workshop. The integration of reclaimed water in water resource management. Gerona, Spain, 2005.

[40] Berga, L., Yagüe, J., Cajete, J., Giron, F., Mendiluce, J.M., Benefits and concerns about dams in Spain. 20th Icold International Congress. Q-77.R35, pp. 519-554. Beijing, 2000.

[41] Demarcación Hidrográfica de las Cuencas Mediterráneas Andaluzas, DHCMA, Plan hidrológico de la demarcación hidrográfica de las cuencas mediterráneas andaluzas. Consejería de Medio Ambiente y Ordenacióndel Territorio. Junta de Andalucía, 2010.

[42] Rodríguez, M.I., Planning and management of regional water networks. VI Envirowater Conference, Delft, Mayo, 2006.

[43] Avilés A., Rodero J., Amores V., de Vicente I., Rodríguez M.I., Niell F.X., Factors controlling phosphorus speciation in a mediterranean basin (River Guadalfeo, Spain. Journal Of Hydrology, 331, pp. 396-408, 2006.

[44] Malisz B., Threshold analysis as a tool in urban and regional planning. Eleventh European Congress Of The Regional Science Association. Papers in Regional Science. 29(1) Springer, 1972.

[45] Grindlay, A.L., Matarán, A., Infraestructuras y políticas del agua y surelación con el territorio del Guadalquivir, Universidad de Granada, Granada, 2010.

[46] Intecsa-Inarsa, Memoria del estudio: aprovechamiento de los recursoshídricos del litoralgranadino (Presa de Rules). Technical Report, 2003.

[47] Plan Blue. Urbanisation in the mediterranean region from 1950 to 1995. Blue Plan Papers 1. Sophia Antipolis, 2003. 